\title{
Measles virus serology in Crohn's disease
}

\author{
N C Fisher, L Yee, P Nightingale, R McEwan, J A Gibson
}

\begin{abstract}
Background-There is evidence that measles virus infection in early life may predispose to Crohn's disease.

Aims-To examine using serological methods a potential association between measles virus infection in early life and predisposition to Crohn's disease.

Subjects-Forty five patients with Crohn's disease and forty five healthy controls were studied prospectively.

Methods-Clinical data were recorded and serum was analysed for measles virus, cytomegalovirus (CMV), adenovirus and herpes simplex virus (HSV) antibody titres by a complement fixation test (CFT), and for measles virus IgM by enzyme linked immunosorbent assay (ELISA).
\end{abstract}

Results-Reciprocal CFT titres for measles virus were lower in patients with Crohn's disease compared with controls $(p<0.05)$; there was no significant difference in titres for other viruses. None of the subjects studied had a level of measles virus IgM suggestive of acute infection, and there was no significant difference in measles virus IgM levels between patients and controls. The measles virus CFT titres and IgM levels in the patients with Crohn's disease did not correlate with any of the clinical features recorded.

Conclusion-This study does not provide supportive evidence for a role for measles virus in the aetiology of Crohn's disease.

(Gut 1997; 41: 66-69)

Keywords: Crohn's disease; measles virus

Gastroenterology

Staffordshire General

Infirmary, Stafford

ST16

N C Fisher

J A Gibson

Department of Microbiology,

Staffordshire General

Infirmary, Stafford

ST16

L Yee

Wolfson Computer Laboratory, Queen

Elizabeth Medical

Centre, Birmingham

B15 2TH

P Nightingale

Public Health

Laboratory Service,

Hartshill,

Stoke-on-Trent

ST4 7PX

R McEwan

Correspondence to Dr N C Fisher,

Liver Unit, Queen Elizabeth

Hospital, Edgbaston,

Birmingham B15 2TH

Accepted for publication

10 March 1997
We examined the serum of patients with Crohn's disease and healthy controls to test the hypothesis that the serological changes in Crohn's disease may be similar to those in SSPE. Antibody levels to measles virus, and other viruses for comparison, were measured.

This study was approved by the South Staffordshire Health Authority Research Ethics Committee.

\section{Methods}

PATIENTS

Patients with Crohn's disease were recruited prospectively on the basis of radiological findings or histological examination of biopsy or resection specimens, or both. A diagnosis of small bowel Crohn's disease was accepted if one or more characteristic strictures were present on radiological contrast examination, with or without confirmatory histological evidence. A diagnosis of large bowel Crohn's disease was only accepted on the basis of confirmatory histology including the presence of granulomata; patients with suspected large bowel Crohn's disease were excluded if histological findings were equivocal.

Healthy controls were recruited from the hospital work force; subjects were excluded if they had any history of acute or chronic gastrointestinal disease, any other active inflammatory disease, or were taking any form of immunosuppressive therapy. We recorded the following features in the patients with Crohn's disease: age, sex, duration of disease, site of disease, history and site of bowel resection, current Harvey-Bradshaw index (HBI), ${ }^{13}$ erythrocyte sedimentation rate (ESR), haemoglobin concentration, serum albumin concentration, and current medication. For the control subjects, we recorded age and sex.

For all patients and controls, serum was collected and stored at $-70^{\circ} \mathrm{C}$ pending analysis. We measured serum CFT titres for measles virus, cytomegalovirus (CMV), herpes simplex virus (HSV), and adenovirus antibodies. The CFT assays were performed using viral antigens provided by the Division of Microbial Reagents at the Central Public Health Laboratory, Colindale, London. Complement and sheep red blood cells were provided by Advanced Protein Products Ltd, UK, and E and $\mathrm{O}$ Laboratories Ltd, UK, respectively. Antigen was incubated with serial dilutions of serum, and antibody was detected by complement dependent lysis of sheep red blood cells sensitised with complement fixing antibodies. CFT titres were thus expressed as the highest dilution of serum yielding a positive result. For all subjects, we also measured measles virus IgM using a commercial enzyme linked 
immunosorbent assay (ELISA) provided by Clark Laboratories Inc, New York, USA. Briefly, serum was incubated with solid phase antigen before the addition of goat anti-human IgM globulin conjugated with horseradish peroxidase. Chromogenic substrate was then added, and quantitative optical density values were obtained using a microwell plate reader.

Stored acute and convalescent serum from two local cases of acute measles virus infection, which had previously shown a fourfold increase in measles virus CFT titre, was used to validate the assays. We were unable to obtain any serum from known cases of SSPE.

Statistical analysis was carried out using Microsoft Excel software and Manugistics STATGRAPHICS software.

\section{Results}

Forty five patients with Crohn's disease (19 men, 26 women, mean age 42 years) and 45 controls (24 men, 21 women, mean age 47 years) were recruited. Of the patients with Crohn's disease, 24 had small bowel disease, 18 large bowel disease, and three mixed disease. Three patients had newly diagnosed disease. Seventeen patients had a history of bowel resection. ESR values varied from 2 to 110 (mean $21 \cdot 6$ ), whereas the HBI varied from 0 to 15 (mean $4 \cdot 0$ ). Eighteen patients were taking no medication at the time of the study, nine were taking a 5-aminosalicylate (5-ASA) derivative (that is, sulphasalazine or mesalazine), and 18 were taking an immunosuppressive agent (prednisolone or azathioprine, or both), with or without a 5-ASA derivative. No patient or control gave a history of recent measles infection or contact with a suspected case.

CFT results for measles virus varied from less than 1 in $10(<1: 10)$ to greater than or equal to 1 in $320(\geq 1: 320)$. For patients with Crohn's disease, the median measles virus titre was $1: 20$ (interquartile range $1: 20$ to $1: 40$ ) whereas for controls the median titre was $1: 40$ (interquartile range $1: 20$ to $1: 160 ; \mathrm{p}<0.05$, Cochran's $\chi^{2}$ test of linear trend ${ }^{14}$; table 1 ). Figure 1 shows the distribution of results.

CFT titres for CMV, HSV and adenovirus varied from 1:10 to $1: 40$ (CMV) and from 1:10 to $1: 80$ (HSV and adenovirus). Median values

TABLE 1 Reciprocal CFT titres for measles and other viruses

\begin{tabular}{|c|c|c|c|}
\hline Virus & $\begin{array}{l}\text { Crohn's } \\
\text { disease }\end{array}$ & Controls & $p$ Value \\
\hline \multicolumn{4}{|l|}{ Measles virus } \\
\hline Range & $<10-160$ & $10->320$ & \\
\hline Median & & & \\
\hline Interquartile range & $20-40$ & $20-160$ & $<0.05$ \\
\hline \multicolumn{4}{|l|}{ HSV } \\
\hline Range & $10-40$ & $10-80$ & \\
\hline Median & 20 & 20 & \\
\hline Interquartile range & $20-40$ & $10-40$ & NS \\
\hline \multicolumn{4}{|l|}{ CMV } \\
\hline Range & $10-40$ & $10-40$ & \\
\hline Median & 10 & 10 & \\
\hline Interquartile range & $10-40$ & $10-20$ & NS \\
\hline \multicolumn{4}{|l|}{ Adenovirus } \\
\hline Range & $10-80$ & $10-80$ & \\
\hline Median & 20 & 20 & \\
\hline Interquartile range & $10-20$ & $10-40$ & NS \\
\hline
\end{tabular}

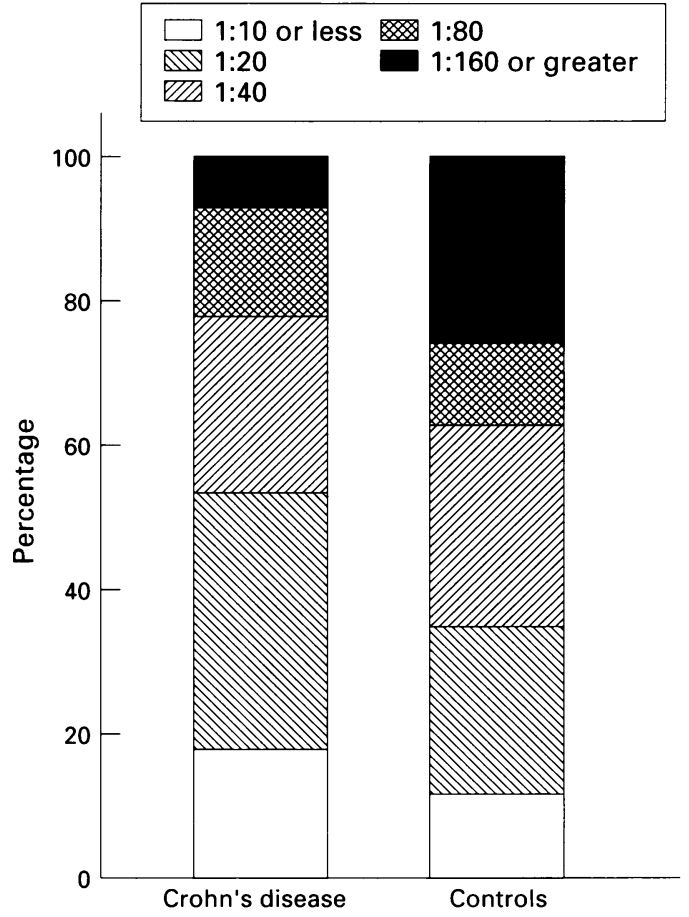

Figure 1: Distribution of CFT titres.

were the same for patients and controls for each of the three viruses, and overall values were not significantly different between patients with Crohn's disease and controls (table 1).

Measles virus IgM levels were not considered diagnostic of recent or acute measles virus infection in any of the patients with Crohn's disease or controls. However, there was a trend towards lower values in patients with Crohn's disease compared with controls. The mean optical density (OD) value in patients with Crohn's disease was 0.128 and was 0.219 in controls (NS) (an OD value of $>1 \cdot 1$ is suggestive of recent infection). Correlation between measles virus CFT titres and IgM levels for all patients and controls combined was poor (Spearman rank coefficient $0 \cdot 04$, NS). For patients with Crohn's disease, measles virus CFT and IgM antibody titres were analysed according to drug therapy; patients were divided into two groups (group 1, 5-ASA derivatives alone or no medication, $\mathrm{n}=27$; group 2 , any immunosuppressive agents with or without 5 -ASA derivatives, $n=18$ ). For CFT titres, there was no significant difference between groups. However, IgM levels were higher in group 2 patients (median values $0 \cdot 18$ $v 0 \cdot 08, \mathrm{p}<0.05$, Mann-Whitney U test) (table 2). Measles virus CFT and IgM antibody titres were also analysed according to site of disease. Median reciprocal CFT values were 20 (small bowel) and 40 (large bowel) (NS). Median values for $\operatorname{IgM}$ were $0 \cdot 12$ (small bowel) and $0 \cdot 14$ (large bowel) (NS). CFT titres for each virus were analysed according to disease characteristics; no significant associations were found (table 3 ).

The three newly diagnosed and untreated patients each had measles virus CFT titres of 1:40, whereas OD values by the IgM assay 
TABLE 2 Concurrent treatment and measles virus serology in patients with Crohn's disease

\begin{tabular}{llll}
\hline Serology & $\begin{array}{l}\text { Nil or 5-ASA } \\
\text { derivative alone } \\
(n=27)\end{array}$ & $\begin{array}{l}\text { Immunosuppressive } \\
\text { agentt } \\
(n=18)\end{array}$ & p Value \\
\hline $\begin{array}{l}\text { CFT } \\
\quad \text { Median } \\
\text { Interquartile range }\end{array}$ & 20 & 20 & $\mathrm{NS} \ddagger$ \\
$\begin{array}{l}\text { IgM } \\
\quad \text { Median } \\
\text { Interquartile range }\end{array}$ & $\begin{array}{l}0-40 \\
0.03-0.27\end{array}$ & $20-40$ & $\mathrm{NS}$ \\
\hline
\end{tabular}

^Mann-Whitney U test.

†Prednisolone or azathioprine, or both, (with or without a 5-ASA derivative).

$\neq$ Cochran's $\chi^{2}$ test of linear trend.
TABLE 3 Disease characteristics and correlations with measles virus titre in patients with Crohn's disease

\begin{tabular}{lll}
\hline Characteristics & $\begin{array}{l}\text { Spearman's rank } \\
\text { correlation coefficient }\end{array}$ & $p$ Value \\
\hline Age & -0.04 & NS \\
Duration of illness & 0.00 & NS \\
ESR & 0.29 & NS \\
HBI & -0.03 & NS \\
\hline
\end{tabular}

$\mathrm{ESR}=$ erythrocyte sedimentation rate.

were $0.39,0 \cdot 17$, and 0.66 compared with the mean of $0 \cdot 128$ for the Crohn's disease group overall.

The paired serum samples from two local cases of acute measles virus infection which had previously shown a fourfold increase in measles virus CFT titre again showed a fourfold increase with our current assay. Measles virus IgM analysis gave a positive result in one case and an equivocal result in the other (OD values 1.17 and $0 \cdot 80$, respectively).

\section{Discussion}

Raised antibody titres to measles virus might be expected in Crohn's disease if there is a causative association between the two diseases, but our study, like a previous study of intrafamilial cases of Crohn's disease, ${ }^{8}$ has failed to find any such association. On the contrary, there was reduced antibody by CFT and a trend towards reduced IgM activity by ELISA in patients with Crohn's disease compared with controls. The inverse association between Crohn's disease and measles virus antibody titres by CFT was not found for other viruses. It is possible that this latter discrepancy was a chance finding as the range of CFT titres for the other viruses tested was low both in patients with Crohn's disease and control groups compared with that for measles virus.

The value of CFT titres in diagnosing measles virus infection is limited; a fourfold increase in titres between acute and convalescent serum is considered essential for confirmation of clinically suspected acute infection, and absolute values may not be helpful. This limitation may apply to our study, but, given the long delay that would separate acute measles virus infection and subsequent Crohn's disease, it would be difficult to obtain meaningful paired samples. It is worth noting that the CFT titres in late SSPE may rise to extremely high levels (characteristically $>1: 1000$ ), ${ }^{11}{ }^{12}$ and no such levels were encountered in any of our patients with Crohn's disease. Although our methods may have differed from those of other workers, and we were unable to obtain serum from validated cases of SSPE to strengthen our findings, the lack of high titres in any of our patients, including three with newly presenting untreated disease, suggests that serological findings in Crohn's disease and SSPE are different.

These observations suggest that if Crohn's disease and SSPE share measles virus as a causative factor, then not only does the target organ differ but so does the immunopathogenesis. Based on current knowledge, it would be difficult to reconcile different models of immunopathogenesis if it were accepted that Crohn's disease shared with SSPE the characteristic of measles virus infection in early life followed by a latent illness with persisting measles virus particles in the target organ. Pathological findings in nervous tissue in cases of SSPE include perivascular inflammation in association with viral particles, ${ }^{10}{ }^{15}$ and it is claimed that similar findings are present in gastrointestinal mucosa affected by Crohn's disease. $^{5}{ }^{16}$

Our concern that CFT titres (measuring predominantly IgG antibody) might not accurately reflect current or reactivated infection led us to perform a measles virus IgM assay; this assay also failed to provide any evidence of measles virus infection in the Crohn's disease group. Although the IgM ELISA for measles virus may have a poor predictive value in diagnosis of acute (or presumably reactivated) infection, with variation between different commercially available assays, ${ }^{17}$ our corroboration of previously identified cases of acute measles and finding of overall similar results to the CFT analysis led us to believe that the assay was valid.

It is possible that a reduction in measles virus antibody titres reflects a generalised depression of host immunity in Crohn's disease. However, we found no such reduction in antibody titres to CMV, HSV, or adenovirus. Furthermore, analysis of other published literature does not suggest any evidence for reduced serum levels of antibodies to viral or bacterial pathogens in Crohn's disease. In contrast, raised levels of antibodies to bacterial pathogens have been found, a phenomenon that is thought to reflect translocation of bacteria across the mucosa of diseased bowel. ${ }^{18}$

A potential shortcoming in our study is a lack of validated historical data for our subjects concerning any history of known or suspected previous measles virus infection. However, previous studies have suggested that a history of measles virus infection does not correlate with level of antibody titres, probably as a result of inaccurate recall or diagnosis. ${ }^{19}$ Likewise, a history of measles immunisation is unreliable, ${ }^{20}$ and we therefore chose not to include these potentially confounding questions in our study.

In summary, our study does not support the hypothesis that measles virus is involved in the causation of Crohn's disease, according to currently accepted models of disease pathogenesis. However, the reduced measles virus 
antibody levels in patients with Crohn's disease compared with controls suggests the possibility of a specific host immune defect and deserves further study. Further information may be gained by studying a more extensive cohort, including newly diagnosed or untreated, or both, cases.

We would like to acknowledge Astra (UK) Ltd for generous financial help, and Mr John Cook of the PHLS, Stoke-onTrent, for help in performing the measles virus IgM assay.

1 Ekbom A, Adami HO, Helmick CG, Jonzon A, Zack MM. Perinatal risk factors for inflammatory bowel disease: a case-control study. Am f Epidemiol 1990; 132: 1111-9.

2 Ekbom A, Wakefield AJ, Zack M, Adami HO. Perinatal measles infection and subsequent Crohn's disease. Lancet 1994; 344: 508-10

3 Thompson NP, Montgomery SM, Pounder RE, Wakefield AJ. Is measles vaccination a risk factor for inflammatory bowel disease? Lancet 1995; 345: 1071-4.

4 Wakefield AJ, Pittilo RM, Sim R, Cosby SL, Stephenson JR, Dhillon AP, et al. Evidence of persistent measles virus infection in Crohn's disease. $\mathscr{f}$ Med Virol 1993; 39: 345-53.

5 Lewin J, Dhillon AP, Sim R, Mazure G, Pounder RE, Wakefield AJ. Persistent measles virus infection of the intestine: confirmation by immunogold electron microscopy. Gut 1995; 36: 564-9.

6 Ekbom A, Daszak P, Kraaz W, Wakefield AJ. Crohn's disease after in-utero measles virus exposure. Lancet 1996; 348: 515-7.

7 Iizuka $M$, Nakagomi O, Chiba M, Ueda S, Masamune $O$. Absence of measles virus in Crohn's disease. Lancet 1995; 345: 199.
8 Touze I, Dubucquoi S, Cortot A, Van Kruiningen HJ, Colombel JF. IgM-specific measles-virus antibody in 1995; 346: 967 .

9 Balzola FA, Khan K, Pera A, Bonino F, Pounder RE, Wakefield AJ. Increased measles IgM immunoreactivity in patients with inflammatory bowel disease [abstract]. Gut 1996; 38 (suppl 1): A14.

10 Poser CM. Notes on the pathogenesis of subacute sclerosing panencephalitis. F Neurol Sci 1990; 95: 219-24

11 Connolly JH, Allen IV, Hurwitz LJ, Millar JHD. Measlesvirus antibody and antigen in subacute sclerosing panencephalitis. Lancet 1967; i: 542-4.

12 Jabbour JT, Sever JL. Serum measles antibody titres in patients with subacute sclerosing panencephalitis, compared with parents and siblings. $f$ Pediatr 1968; 73: pared 7 .

13 Harvey RF, Bradshaw JM. A simple index of Crohn's disease activity. Lancet 1980; ii: 514

4 Cochran WG. Some methods for strengthening the common $\chi^{2}$ tests. Biometrics 1954;10: 417-41.

15 Wisniewski HM, Brown HR, Thormar H. Pathogenesis of viral encephalitis: demonstration of viral antigen(s) in the brain endothelium. Acta Neuropathol 1983; 60: 107-12.

16 Wakefield AJ, Sankey EA, Dhillon AP, Sawyerr AM, More L, Sim R, et al. Granulomatous vasculitis in Crohn's disease. Gastroenterology 1991; 100: 1279-87.

17 Ramsay M, Cohen B, Brown D. Serum IgM testing is needed in all cases of suspected measles [letter]. $B M \mathcal{F}$ 1996; 313: 231 .

18 Blaser JM, Miller RA, Lacher J, Singleton JW. Patients with active Crohn's disease have elevated serum antibodies to antigens of seven enteric bacterial pathogens. Gastroenterology 1984;87: 888-94.

19 Kim M, LaPointe J, Liu FJ. Epidemiology of measles immunity in a population of healthcare workers. Infect immunity in a population of healthcare wo

20 Thompson NP, Pounder RE, Wakefield AJ. Perinatal and childhood risk factors for inflammatory bowel disease: a case-control study. Eur $\mathcal{f}$ Gastroenterol Hepatol 1995; 7; 385-90. 